\title{
Otitis Media Supuratif Kronis Tipe Kolesteatom dengan Komplikasi Sekuele Stroke Akibat Meningoensefalitis
}

\author{
Debby Apri Grecwin ${ }^{1}$, Yan Edward ${ }^{2}$
}

\begin{abstract}
Abstrak
Otitis media supuratif kronis tipe kolesteatom bisa menyebabkan komplikasi ekstrakranial dan intrakranial. Meningitis merupakan komplikasi intrakranial dari otitis media supuratif kronis yang paling sering terjadi. Meningitis bakteri dapat menyebabkan terjadinya stroke. Terapi medikamentosa dengan antibiotik intravena spektrum luas dan tindakan operasi akan memberikan outcome yang baik. Dilaporkan seorang pasien anak laki-laki usia 13 tahun dengan diagnosis otitis media supuratif kronis auris dekstra tipe kolesteatom dengan komplikasi sekuele stroke akibat meningoensefalitis yang ditatalaksana dengan terapi medikamentosa dan timpanomastoidektomi dinding runtuh. Penatalaksanaan otitis media supuratif kronis tipe kolesteatom dengan komplikasi sekuele stroke akibat meningoensefalitis terdiri dari terapi medikamentosa yang adekuat dan timpanomastoidektomi dinding runtuh untuk menghilangkan sumber infeksi di telinga tengah.
\end{abstract}

Kata kunci: otitis media supuratif kronis tipe kolesteatom, komplikasi intrakranial, meningitis, stroke

\begin{abstract}
Chronic suppurative otitis media with cholesteatoma could cause extracranial and intracranial complications. Meningitis is the most common intracranial complications of chronic suppurative otitis media. Bacterial meningitis could lead into stroke. Broad spectrum antibiotics intravenously along with the surgery give the good outcome. Reported a case of 13-year-old boy with diagnosis with chronic suppurative otitis media with cholesteatoma at right ear with stroke sequele complication resulted meningoencephalitis. Patient was treated with medicamentosa and canal wall down tympanomastoidectomy surgery. The management of chronic suppurative otitis media with stroke sequele resulted meningoencephalitis is medicamentosa adequately and canal wall down tympanomastoidectomy surgery to eliminate the source of infection from middle ear.
\end{abstract}

Keywords: chronic suppurative otitis media cholesteatoma type, intracranial complication, meningitis, stroke

Affiliasi penulis: 1. Program Pendidikan Dokter Spesialis-1 THT-KL Fakultas Kedokteran Universitas Andalas Padang (FK Unand), 2. Bagian THT-KL FK Unand/RSUP Dr.M.Djamil Padang

Korespondensi: apri_grec@yahoo.com Telp: 082385432321

\section{PENDAHULUAN}

Otitis Media Supuratif Kronis (OMSK) masih menjadi salah satu penyakit infeksi kronis yang paling sering terjadi pada anak di seluruh dunia. ${ }^{1}$ Penyakit ini banyak ditemui pada populasi dengan strata sosial ekonomi rendah dan tinggal pada daerah rural, dengan kondisi higienitas dan diet yang buruk. ${ }^{2}$

Otitis media supuratif kronis tipe kolesteatom bisa menyebabkan komplikasi ekstrakranial dan intrakranial. $^{2}$ Hampir $70 \%$ komplikasi intrakranial terjadi pada dua dekade pertama kehidupan. ${ }^{3}$ Penelitian Mustafa et al (2014) mendapatkan dari total 2.765 pasien OMSK, sebanyak 502 (18,08\%) merupakan tipe kolesteatom. Dari 502 pasien ditemukan sebanyak 145 pasien mengalami komplikasi, 33,79\% di antaranya ke intrakranial. ${ }^{4}$

Meningitis merupakan komplikasi intrakranial yang paling sering terjadi. ${ }^{5}$ Penelitian Dubey et al mendapatkan bahwa meningitis merupakan komplikasi intrakranial dari OMSK yang paling sering ditemui, yaitu $43,7 \%$, diikuti trombosis sinus lateral $(31,2 \%)$ dan abses serebelum (18,7\%). ${ }^{6}$ Penelitian Mostafa et al memperoleh hasil dari total 422 pasien otitis media dengan komplikasi (402 pasien di antaranya OMSK 
tipe kolesteatom) didapatkan komplikasi intrakranial yang paling sering adalah trombosis sinus lateralis (TSL) sebanyak $29 \%$, diikuti oleh abses otak (21\%), abses serebelum (16,5\%) dan meningitis $(12,5 \%){ }^{7}$ Penelitian Jain et al di India mengenai komplikasi intrakranial OMSK pada anak mendapatkan abses otak merupakan komplikasi yang paling sering, diikuti meningitis dan TSL. ${ }^{8}$

Meningitis bakteri dapat menyebabkan stroke sebanyak $17-43 \%$ kasus. ${ }^{9}$ Stroke relatif jarang terjadi pada anak-anak, tetapi bisa menyebabkan morbiditas dan mortalitas yang signifikan., 9

\section{Otitis Media Supuratif Kronis Tipe Kolesteatom}

Definisi OMSK adalah inflamasi telinga tengah akibat infeksi yang ditandai dengan otore kronis ( $>12$ minggu) dari membran timpani yang perforasi. ${ }^{1}$ Kolesteatom merupakan kista inklusi epidermal telinga tengah atau mastoid. ${ }^{3,4}$ Berdasarkan patogenesisnya, kolesteatom dibagi menjadi kolesteatom kongenital dan kolesteatom akuisita (primer dan sekunder). Kolesteatom kongenital berkembang dari embryonic epithelial rests dan bisa berlokasi di semua bagian tulang temporal. Kolesteatom akuisita primer berkembang di belakang membran timpani yang intak, biasanya di daerah pars flaksida. Kolesteatom akuisita sekunder tumbuh ke telinga tengah melalui membran timpani yang perforasi, biasanya melalui pars tensa dan kadang-kadang pars flaksida. ${ }^{11,12}$

Kolesteatom merupakan epitel kanalis auditorius eksternal yang berkeratinisasi ke telinga tengah, menyebabkan erosi struktur di sekitarnya. ${ }^{4}$ Teori tentang patogenesis terbentuknya kolesteatom akuisita yang banyak diterima adalah terjadinya retraksi pada membran Shrapnell atau kuadran postero-superior pars tensa yang berkembang menjadi kista dan berisi debris epitel yang bersifat erosif lokal. Teori patogenesis yang lain adalah teori migrasi, hiperplasia sel basal, implantasi dan metaplasia skuamosa. ${ }^{11,12}$

\section{Komplikasi OMSK Tipe Kolesteatom}

Komplikasi OMSK dibagi menjadi intratemporal (fistula labirin, paralisis nervus fasialis, abses mastoid, petrositis dan labirintitis) dan ekstratemporal. Komplikasi ekstratemporal terdiri dari: ${ }^{13,14}$
1. Intrakranial: jaringan granulasi atau abses ekstradural, tromboflebitis sinus lateral, meningitis, abses otak, meningoensefalokel, hidrosefalus otik dan abses subdural.

2. Ekstrakranial: abses subperiosteal dan abses Bezold

\section{Patofisiologi OMSK dengan Komplikasi}

Infeksi telinga tengah cenderung menyebar ke daerah sekitar dipengaruhi oleh faktor neglected pathology, virulensi kuman, ketahanan host, terapi antibiotik yang adekuat, barrier anatomi dan drainase ruang pneumatik. Jalur komplikasi ekstra dan intrakranial meliputi tromboflebitis venula tulang kranial yang berdekatan, erosi tulang oleh tekanan atau kerja enzimatik, jalur yang sudah terbentuk dan hematogen (gambar 1). Barrier tulang telinga tengah dapat mengalami erosi oleh osteitis, jaringan granulasi atau kolesteatom. Kondisi ini menyebabkan infeksi menyebar ke intrakranial. ${ }^{5}$

\section{Meningoensefalitis dengan Sekuele Stroke}

Meningitis merupakan inflamasi yang melibatkan meningen sedangkan ensefalitis merupakan inflamasi yang melibatkan parenkim otak. ${ }^{15}$ Secara klinis, meningitis dan ensefalitis sering sulit dibedakan. ${ }^{16}$ Meningitis yang disebabkan oleh otitis media terjadi akibat penyebaran infeksi secara langsung melalui dura atau hematogen. Di samping itu, meningitis juga bisa disebabkan oleh perluasan dari labirintitis supuratif di sepanjang cabang nervus VIII atau melalui jalur yang sudah terbentuk sebelumnya (misal akuaduktus koklea) atau fistula labirin yang diinduksi oleh kolesteatom. ${ }^{5}$

Gejala predominan adalah sakit kepala hebat dan nausea, penurunan kesadaran, demam, fotofobia, hiperestesia. ${ }^{3}$ Manifestasi klinis lain berupa kaku kuduk dan nyeri saat leher difleksikan, tanda Brudzinski, fleksi pasif kepala ke dada diikuti oleh fleksi involunter kedua tungkai atas dan bawah. ${ }^{13}$

Pungsi lumbal merupakan tindakan diagnostik untuk mengetahui organisme kausatif. Hasil pungsi lumbal yang ditemukan pada pasien meningitis berupa peningkatan tekanan awal, liquor cerebro spinal (LCS) tinggi protein, rendah glukosa dan peningkatan sel darah putih yang memberikan gambaran cloudy 
appearance. Liquor cerebro spinal dikirim untuk pemeriksaan pewarnaan gram dan kultur. Tomografi komputer (TK) dilakukan untuk menyingkirkan abses otak, serebritis, empiema subdural dan bisa menentukan apakah pungsi lumbal aman dilakukan. ${ }^{13}$

Antibiotik intravena (iv) sefalosporin generasi ketiga dan vankomisin harus diberikan sementara menunggu hasil kultur. Steroid (deksametason) secara signifikan menurunkan angka kematian dan gangguan pendengaran pada pasien dengan meningitis pneumococcal. $^{13}$ Berdasarkan beberapa publikasi terakhir, para ahli menyetujui bahwa meningitis otogenik harus ditatalaksana dengan operasi telinga tengah (mastoidektomi simpel atau radikal) dan kombinasi dengan antibiotik. Tindakan mastoidektomi harus dilakukan untuk menghilangkan sumber infeksi ketika pasien dalam keadaan stabil. ${ }^{4,5}$

Beberapa bakteri yang sering menyebabkan sekuele stroke pada meningitis adalah Streptococcus pneumoniae, Neisseria meningitidis, streptoccous grup $\mathrm{B}$, Listeria monocytogenes dan Haemophilus influenzae. Bakteri yang berada di dalam LCS akan menstimulasi respon imun host, sehingga terjadi

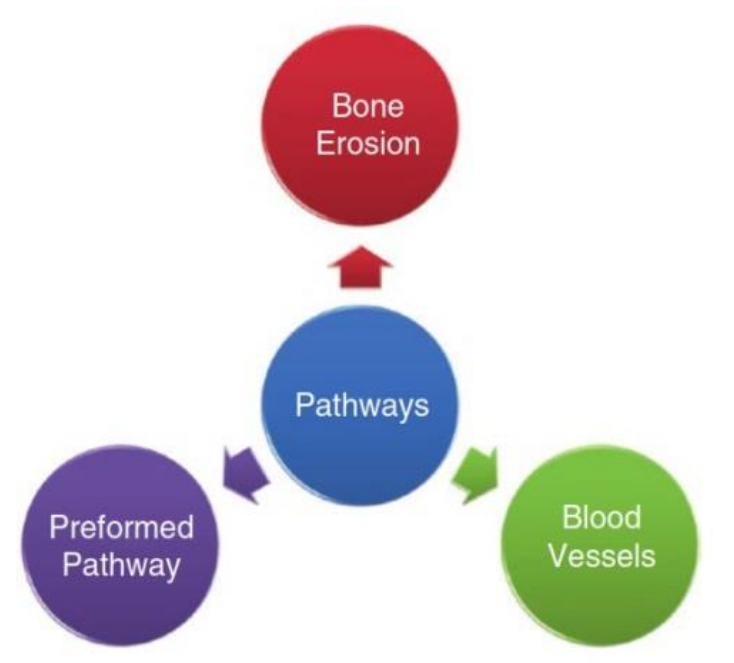

Gambar 1. Jalur penyebaran infeksi OMSK ke intrakranial. $^{5}$ kerusakan sel-sel endotel. Kerusakan ini akan mengganggu autoregulasi dan integritas sawar darah otak yang nantinya akan menyebabkan edema serebri dan peningkatan tekanan intrakranial (TIK). Proses akhir dari kondisi ini adalah iskemia akibat berkurangnya perfusi ke parenkim otak. ${ }^{17}$ Mekanisme lain terjadinya sekuele stroke akibat meningitis adalah akibat penyebaran inflamasi meningen ke dinding pembuluh darah intrakranial dan menyebabkan trombosis arteri dengan iskemia atau ruptur dengan perdarahan. $^{18}$

\section{Prognosis}

Dubey mendapatkan angka mortalitas OMSK dengan komplikasi intrakranial sebanyak $31,2 \%$. Hal ini disebabkan oleh infeksi yang memberat atau septikemia dan peningkatan tekanan intrakranial. ${ }^{6}$ Pasien anak dengan meningoensefalitis akan mengalami sekuele neurologis sebanyak kira-kira $30 \%$. Dunbar mendapatkan mortalitas meningitis dengan komplikasi stroke lebih tinggi (25\%) dibandingkan dengan tanpa stroke (4\%). ${ }^{9}$

\section{KASUS}

Seorang pasien anak laki-laki usia 13 tahun dikonsulkan dari Bagian Anak di IGD RSUP Dr. M. Djamil Padang pada tanggal 19 April 2016 dengan suspek ensefalitis dan OMSK auris dekstra (AD) tipe kolesteatom. 
Pasien mengalami penurunan kesadaran sejak dua hari sebelum masuk rumah sakit. Penurunan kesadaran diawali dengan kejang seluruh tubuh yang berulang 6-8 kali/ hari. Pasien dirawat oleh dokter Spesialis Anak selama dua hari di RSUD Pasaman dan mendapatkan terapi sefotaksim $3 \times 1,5$ gram (iv), ampisilin 6x1,2 gram (iv), metronidazol infus $3 \times 350$ $\mathrm{mg}$, deksametason $3 \times 4 \mathrm{mg}$ (iv), luminal $2 \times 75 \mathrm{mg}$ per nasogastric tube (NGT) dan parasetamol 4x250 mg per NGT, karena tidak ada perbaikan pasien dirujuk ke RSUP Dr. M. Djamil Padang. Riwayat nyeri kepala hebat disertai muntah tidak menyemprot dan demam hilang timbul sejak sembilan hari sebelumnya. Keluar cairan berbau terus menerus berwarna kekuningan dari telinga kanan ada sejak satu bulan sebelumnya. Riwayat keluar cairan hilang timbul dari kedua telinga

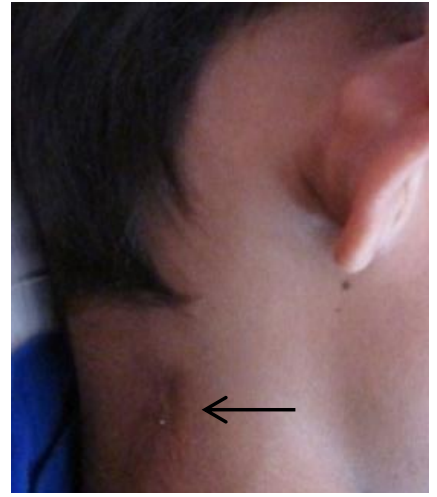

Gambar 2. Jaringan sikatrik di regio colli posterior

Pemeriksaan otoskopi auris sinistra (AS) didapatkan liang telinga lapang, membran timpani perforasi sentral, sekret mukopurulen. Retroaurikula dekstra dan sinistra tidak ditemukan kelainan. Kavum nasi dekstra dalam batas normal, kavum nasi kiri terpasang

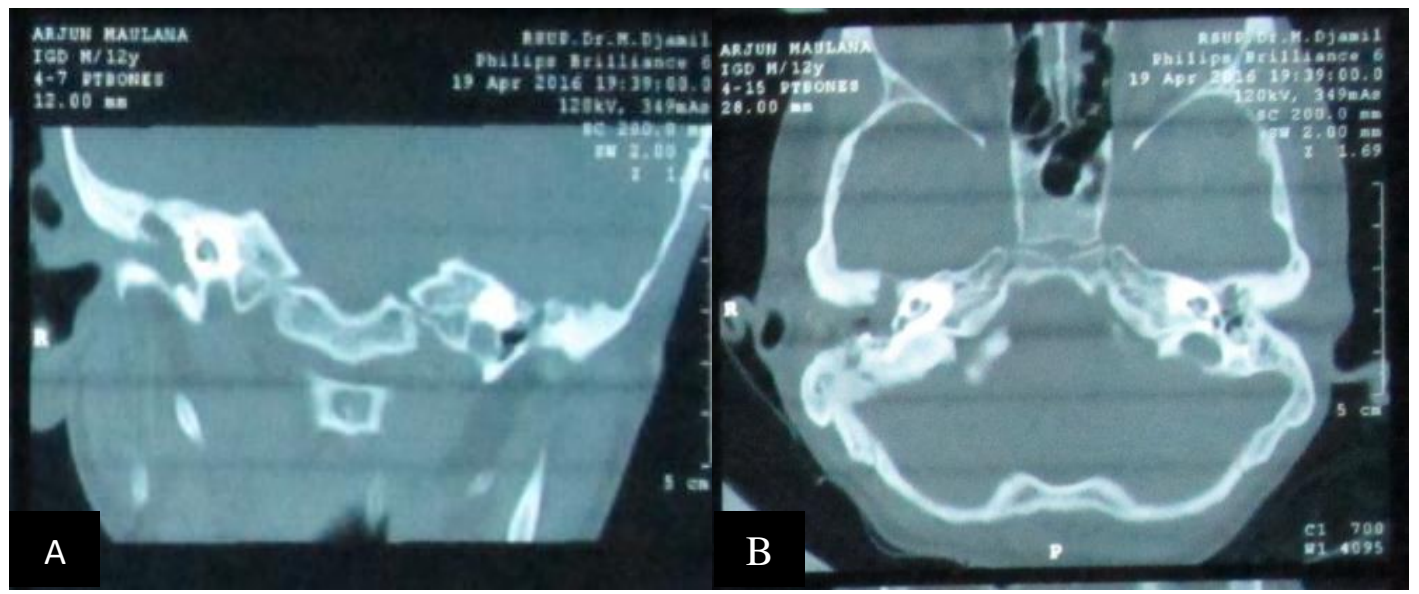

Gambar 3. Tomografi komputer mastoid potongan koronal (A) dan aksial (B), didapatkan gambaran mastoiditis bilateral

ada sejak usia empat bulan. Penurunan pendengaran ada. Tidak ada wajah mencong, riwayat pusing berputar dan lemah anggota gerak satu sisi. Riwayat bengkak di leher belakang sebelah kanan dan mengeluarkan nanah ada dua tahun yang lalu. Tidak ada riwayat batuk-batuk lama, berkeringat malam dan kontak dengan penderita batuk-batuk lama. Batuk pilek tidak ada

Keadaan umum tampak sakit berat dengan GCS $9\left(E_{3} \mathrm{M}_{5} \mathrm{~V}_{1}\right)$, tanda vital dalam batas normal. Berat badan $24 \mathrm{~kg}$. Pupil dalam batas normal. Tanda rangsang meningeal (kaku kuduk, Brudzinsky dan Kernig) tidak ada. Pemeriksaan thoraks dalam batas normal.

Pemeriksaan otoskopi $A D$ didapatkan jaringan granulasi di $2 / 3$ medial liang telinga, sekret mukopurulen, membran timpani sukar dinilai. nasogastric tube (NGT). Tenggorok dalam batas normal. Tampak jaringan sikatrik pada regio colli posterior (gambar 2). Pemeriksaan nervus fasialis perifer, tes penala, tes keseimbangan sederhana, tes koordinasi dan audiometri tidak bisa dilakukan.

Pemeriksaan laboratorium darah didapatkan kesan leukositosis, hasil lain dalam batas normal. Tomografi komputer mastoid didapatkan gambaran perselubungan pada kanalis akustikus eksternus, kavum timpani, antrum dan peri antrum mastoid kanan. Skutum, tulang-tulang pendengaran, tegmen timpani dan tulang mastoid kanan tampak destruksi (gambar 3). Tomografi komputer kepala tanpa kontras menggambarkan lesi hipodens luas di daerah parietal kanan meluas ke kiri sehingga diferensiasi substansia grisea dan alba menghilang. Kesan suspek serebritis dengan edema serebri. Pasien dianjurkan menjalani 
pemeriksaan TK kepala dengan kontras. Pasien didiagnosis dengan OMSK AD suspek tipe kolesteatom dengan komplikasi intrakranial (suspek ensefalitis dengan diagnosis banding abses serebri, meningitis purulenta) dan OMSK AS tipe tanpa kolesteatom fase aktif.

Pasien dikonsulkan ke Bagian Bedah Saraf dan Mata. Bagian Bedah Saraf menegakkan diagnosis serebritis parietal dekstra dan edema serebri dan menyatakan tidak ada indikasi untuk dilakukan tindakan khusus. Bagian Mata tidak menemukan adanya tanda-tanda peningkatan tekanan intrakranial. Pasien dirawat bersama dengan subbagian Otologi di High Care Unit (HCU) Anak, diberikan $\mathrm{O}_{2}$ 21/ menit, Intra vena fluid drip (IVFD) 2A 22 tetes/menit (makro), ampisilin 6x1,2 gram (IV), kloramfenikol 4x600 mg (IV), metronidazol $3 \times 350 \mathrm{mg}$ (infus), deksametason $3 \times 4 \mathrm{mg}$ (IV), luminal $2 \times 60 \mathrm{mg}$ per NGT, parasetamol $3 \times 250 \mathrm{mg}$ per NGT bila demam, $\mathrm{H}_{2} \mathrm{O}_{2} \quad 3 \%$ dan ofloksasin tetes telinga masing-masing $2 \times 5$ tetes pada kedua telinga. Pasien dipuasakan dan direncanakan untuk kultur/ uji sensitivitas darah dan sekret telinga serta pungsi lumbal.

Hari kedua rawatan (21 April 2016), anak membuka mata dengan spontan tetapi kontak dengan lingkungan tidak ada. Anak hanya diam saat diajak berkomunikasi. Keluar cairan kekuningan berbau dari kedua telinga masih ada. Tidak ada wajah mencong, kejang, muntah dan demam. Keadaan umum tampak sakit berat dengan GCS $10\left(E_{4} M_{5} V_{1}\right)$. Tanda rangsang meningeal tidak ada. Pemeriksaan otoskopi ADS didapatkan sekret mukopurulen. Pemeriksaan feses dan urinalisa dalam batas normal. Hasil pungsi lumbal diperoleh kesan meningitis bakteri. Pasien didiagnosis dengan meningoensefalitis. Pasien mendapatkan diet makanan cair $6 \times 200 \mathrm{cc}$ per NGT, dosis metronidazol diturunkan menjadi $3 \times 175 \mathrm{mg}$, furosemid 1×24 mg (iv), manitol (iv) secara bertahap, terapi lain dilanjutkan.

Hari rawatan ke-8 (27 April 2016), kontak dengan lingkungan belum ada, anak masih diam saat diajak berkomunikasi, keluar cairan kekuningan berbau dari kedua telinga sudah berkurang. Tidak ada wajah mencong, kejang, muntah dan demam. Keadaan umum tampak sakit berat dengan GCS 10 $\left(E_{4} M_{5} V_{1}\right)$. Tanda rangsang meningeal tidak ada. Pemeriksaan ADS didapatkan sekret mukopurulen.

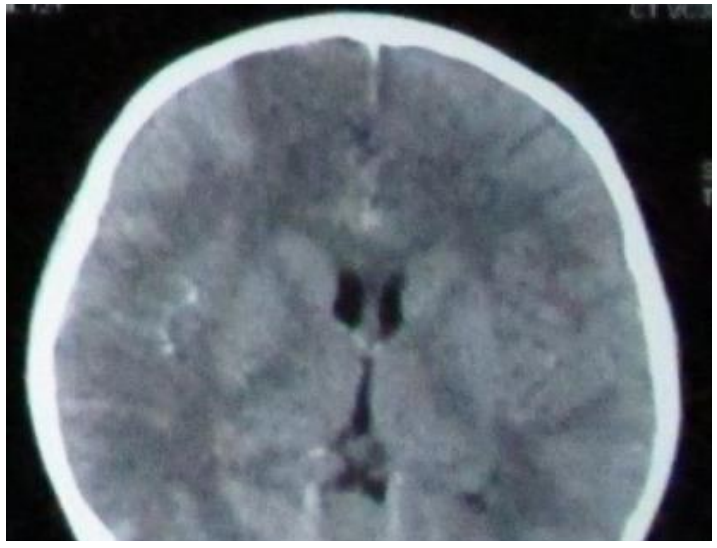

Gambar 4. Tomografi komputer kepala (kontras) potongan aksial: infark serebri luas di hemisfer kanan dan frontoparietal kiri.

Hasil kultur-sensitivitas darah dan sekret telinga ditemukan bakteri Staphylococcus aureus yang sensitif terhadap sefoperazon, gentamisin dan levofloksasin. Hasil kultur LCS tidak ditemukan pertumbuhan kuman. Hasil TK kepala dengan kontras menggambarkan infark serebri luas di hemisfer kanan dan frontoparietal kiri (gambar 4). Ampisilin dan kloramfenikol diganti dengan sefoperazon 3×1,2 gram, aff deksametason dan terapi lain dilanjutkan.

Dua minggu rawatan (3 Mei 2016), kontak dengan lingkungan belum ada, anak masih diam bila diajak berkomunikasi, anggota gerak sisi kiri tampak lebih lemah dibandingkan kanan, keluar cairan dari kedua telinga masih ada tapi sudah berkurang. Tidak ada wajah mencong, kejang, muntah dan demam. Keadaan umum tampak sakit sedang, kesadaran composmentis. Tanda rangsang meningeal tidak ada. Kekuatan otot ekstremitas atas dan bawah sisi kiri $3 / 3 / 3$. Pasien diberikan tambahan terapi piracetam $3 \times 360 \mathrm{mg}$ dan vitamin B6 1×10 mg per NGT. Pasien dikonsulkan ke Bagian Rehabilitasi Medik.

Tiga minggu rawatan (10 Mei 2016) dilakukan timpanomastoidektomi dinding runtuh AD. Pasien tidur telentang dalam anestesi umum, dilakukan tindakan aseptik dan antiseptik. Evaluasi liang telinga, tampak jaringan granulasi pada kavum timpani. Infiltrasi adrenalin 1:200.000 pada sulkus RAD dan liang telinga, kemudian dilakukan insisi pada kulit $\pm 5 \mathrm{~mm}$ dari sulkus RAD dari superior ke inferior mengikuti lengkung posterior aurikula. Dilakukan pengambilan graft dari fasia muskulus temporalis profunda. Insisi 
diperdalam sampai tulang mastoid. Jaringan lunak dipisahkan secara tumpul dari tulang mastoid, tampak destruksi tulang mastoid dan dinding posterior liang telinga. Dilakukan pengeboran pada segitiga Mc. Ewen, tampak jaringan granulasi dan kolesteatom mengisi kavum mastoid, jaringan patologis dibersihkan, nervus fasialis, tegmen dan sinus sigmoid tidak terpapar. Kanalis semisirkularis (KSS) lateral tampak erosi, fistel tidak ada. Identifikasi aditus ad antrum, fosa inkudis, solid angle dan nervus fasialis pars vertikal. Tampak kavum timpani terisi jaringan granulasi dan kolesteatom, tidak ditemukan tulangtulang pendengaran. Jaringan patologis dibersihkan secara maksimal. Dinding posterior liang telinga diruntuhkan. Dilakukan obliterasi dan meatoplasti, cacahan kartilago konka dipasang menutupi KSS, kemudian dipasang graft fasia dan flap. Dilakukan fiksasi dengan spongostan. Diletakkan tampon yang sudah dilapisi dengan salep antibiotik. Luka operasi ditutup dengan jahitan lapis demi lapis.

Satu hari pasca operasi, pasien berbicara tanpa tujuan (meracau). Tidak ada darah merembes dari perban, wajah mencong, kejang dan demam. Tiga hari pasca operasi dilakukan aff tampon luar, tampak luka jahitan di sulkus retroaurikula dekstra tenang. Darah merembes dari tampon di liang telinga kanan tidak ada.

Sepuluh hari pasca operasi, anak masih meracau, anggota gerak sisi kiri masih tampak lemah, kejang dan demam tidak ada,. Tanda rangsang meningeal tidak ada. Kekuatan otot ekstremitas atas dan bawah kiri $3 / 3 / 3$. Liang telinga kanan terpasang tampon kassa, darah mengalir tidak ada. Luka operasi pasca aff hecting tiga hari sebelumnya tampak tenang.

Dua minggu pasca operasi, anak masih meracau, anggota gerak sisi kiri masih tampak lemah, keluar darah dari telinga kanan tidak ada, kejang dan demam tidak ada. Tanda rangsang meningeal tidak ada. Kekuatan otot ekstremitas atas dan bawah 3/3/3. Pemeriksaan otoskopi $A D$ didapatkan liang telinga lapang, sekret mukoid, graft tumbuh dengan baik. Hasil kultur darah ulang tidak ditemukan pertumbuhan kuman. Pasien diperbolehkan pulang dan disarankan untuk kontrol ke poli THT. Pasien diberikan terapi luminal 2x60 mg, piracetam 3×360 mg, vitamin B6 $1 \times 10 \mathrm{mg}$, asam folat $2 \times 1$ tablet dan ofloksasin $2 \times 5$ tetes.

Dua tahun pasca operasi (alloanamnesis via telepon), pasien sudah dapat berinteraksi dengan keluarga, anggota gerak sisi kiri masih lemah, keluar cairan dari telinga kanan ada. Pasien kontrol ke poliklinik THT Rumah Sakit Umum Daerah Pekanbaru, tetapi tidak teratur.

\section{PEMBAHASAN}

Dilaporkan satu kasus OMSK AD tipe kolesteatom dengan komplikasi intrakranial, meningoensefalitis pada anak laki-laki usia 13 tahun. Kira-kira $66 \%$ komplikasi intrakranial akibat otitis media terjadi pada usia <25 tahun. ${ }^{19}$ Tyagi mendapatkan pasien OMSK dengan komplikasi intrakranial yang berusia 10-25 tahun sebanyak 42\%. ${ }^{1}$ Laki-laki lebih sering mengalami komplikasi dibandingkan wanita. $^{6}$ Mustafa mendapatkan komplikasi OMSK tipe kolesteatom pada pria 60,4\%. ${ }^{4}$

Prevalensi komplikasi intrakranial akibat OMSK 4 kali lebih tinggi dibandingkan OMA. ${ }^{18}$ Dubey mendapatkan meningitis merupakan komplikasi yang paling sering terjadi $(43,7 \%)$, diikuti trombosis sinus lateral $(31,2 \%)$ dan abses serebelum $(18,7 \%) .{ }^{6}$ Tyagi juga mendapatkan bahwa meningitis merupakan komplikasi intrakranial dari OMSK yang paling sering terjadi, yakni sebanyak 50\%. ${ }^{1}$ Mustafa melakukan studi retrospektif mengenai tatalaksana komplikasi OMSK tipe kolesteatom selama 10 tahun di Kosovo mendapatkan bahwa komplikasi intrakranial sebanyak $31,9 \%$ dan meningtis merupakan komplikasi yang paling sering terjadi $(19,7 \%){ }^{4}$

Diagnosis OMSK tipe kolesteatom dengan komplikasi meningoensefalitis ditegakkan berdasarkan anamnesis, pemeriksaan fisik, TK kepala tanpa dan dengan kontras serta pungsi lumbal. Manifestasi klinis komplikasi intrakranial pada pasien ini adalah penurunan kesadaran, kejang, sakit kepala, demam dan otore. Dubey mendapatkan gejala dan tanda OMSK dengan komplikasi intrakranial berupa otore dan demam pada semua pasien, sakit kepala $50 \%$, kejang $(12,5 \%)$ dan perubahan status mental $(9,3 \%){ }^{6}$ 
Pasien didiagnosis dengan ensefalitis sebelum dilakukan pemeriksaan pungsi lumbal, karena tidak ditemukannya tanda rangsang meningeal dan hasil TK kepala tanpa kontras yang menggambarkan serebritis dan edema serebri. Hasil pungsi lumbal pada pasien ini menyatakan adanya meningitis bakteri. Namun, hasil kultur LCS menunjukkan tidak ditemukan adanya pertumbuhan kuman. Penelitian Khajeh et al (2015) di Iran pada pasien anak dengan meningoensefalitis mendapatkan tidak ditemukannya pertumbuhan kuman pada kultur LCS sebanyak 48 dari 54 kasus. Hasil ini mungkin disebabkan oleh pemberian antibiotik sebelum dilakukan kultur LCS. ${ }^{20}$

Dua minggu rawatan atau kira-kira tiga minggu sejak pasien mengalami sakit kepala hebat yang disertai demam, pasien mengalami hemiparese, dimana terjadi kelemahan pada anggota gerak sisi kiri. Stroke ini sesuai dengan gambaran infark luas di hemisfer kanan pada TK kepala dengan kontras.

Hemiparese pada pasien ini mungkin disebabkan oleh perjalanan dari meningoensefalitis karena pasien sudah diberikan terapi antibiotik empiris lini pertama maupun definitif sesuai dosis. Meningitis dapat menyebabkan arteritis serebri, yang merupakan faktor risiko terjadinya stroke iskemik arteri. ${ }^{9}$ Kurang dari $1 \%$ pasien OMSK menderita stroke. ${ }^{21}$

Pasha melaporkan satu kasus stroke iskemik masif pada seorang pasien anak perempuan usia 3 tahun, komplikasi dari otitis media akut. Komplikasi ini merupakan bentuk yang jarang, mekanismenya diduga akibat penyebaran inflamasi meningen ke dinding pembuluh darah intrakranial dan menyebabkan trombosis arteri dengan iskemia atau ruptur dengan perdarahan. ${ }^{18}$

Prediktor risiko terjadinya stroke pada anak dengan meningitis di antaranya kejang, adanya fokal neurologis, demam, penurunan kesadaran dan hidrosefalus. ${ }^{9}$ Faktor risiko kejang, demam dan penurunan kesadaran ditemukan pada pasien ini. Dunbar mendapatkan kejadian stroke akibat meningitis lebih sering terjadi pada pasien yang mengalami kejang sebelum atau selama rawatan. ${ }^{9}$

Pasien juga mengalami afasia, pada awal rawatan pasien hanya diam saat diajak berkomunikasi. Afasia merupakan gangguan bahasa pasca kerusakan otak di daerah ganglia basal, thalamus dan hemisfer terutama kiri yang mempengaruhi beberapa atau semua modalitas bahasa, seperti ekspresi dan memahami pembicaraan, membaca dan menulis. ${ }^{22}$ Tomografi komputer kepala dengan kontras pada pasien ini menggambarkan adanya infark di frontoparietalis kiri.

Hasil kultur dan uji sensitivitas darah dan sekret telinga didapatkan bakteri Staphylococcus aureus. Yorgancilar mendapatkan bakteri yang paling sering ditemukan pada pasien OMSK dengan komplikasi adalah Staphylococcus aureus dan Pseudomonas aeruginosa. $^{23}$ Mostafa mendapatkan bakteri yang paling sering adalah Streptococcus pneumoniae, Haemophilus influenza dan Streptococcus pyogenes. ${ }^{7}$

Pasien diberikan terapi antibiotik sebelum dilakukan tindakan operasi. Antibiotik empiris untuk meningitis bakteri adalah sefalosporin generasi ketiga dan vankomisin. ${ }^{13}$ Pasien juga diberikan deksametason intravena. Steroid diberikan untuk mengatasi edema serebri, hipertensi intrakranial dan paralisis nervus kranialis. ${ }^{18}$

Tindakan mastoidektomi dinding runtuh dilakukan tiga minggu pasca terapi medikamentosa. Berdasarkan Kolegium IImu Kesehatan TH-KL, mastoidektomi pada OMSK dengan komplikasi intrakranial bisa dilakukan bersamaan atau setelah dilakukan tindakan operasi oleh Bedah Saraf. ${ }^{24}$ Apabila Bedah Saraf tidak melakukan operasi, mastoidektomi bisa dilakukan setelah pemberian terapi medikamentosa selama 1-2 bulan. Dubey et al (2010) menyatakan bahwa 96,8\% pasien OMSK dengan komplikasi intrakranial menjalani operasi mastoidektomi dinding runtuh dan pada semua kasus ditemukan kolesteatom dengan atau tanpa jaringan granulasi di kavum timpani. ${ }^{6}$

Anestesi dengan teknik hipotensi terkontrol merupakan metode yang diperlukan pada operasi telinga tengah untuk mengurangi perdarahan dan memperbaiki visualisasi lapangan operasi. Namun teknik ini dapat menyebabkan komplikasi seperti pemulihan pasca operasi yang lambat, trombosis serebri, iskemia otak, kerusakan otak permanen dan kematian. ${ }^{25,26,27}$ Keadaan pasien yang meracau pasca tindakan operasi mungkin disebabkan oleh perburukan kerusakan otak yang sudah ada sebelumnya akibat teknik hipotensi ini. Namun kerusakan yang terjadi 
bersifat sementara. Hal ini dibuktikan dengan fungsi kognitif pasien yang kembali mengalami perbaikan beberapa waktu kemudian.

\section{SIMPULAN}

Otitis media supuratif kronis tipe kolesteatom dapat menyebabkan komplikasi intrakranial, yang paling sering adalah meningitis. Dalam proses perjalanan penyakit, meningitis dapat menyebabkan terjadinya stroke. Penatalaksanaan OMSK dengan komplikasi intrakranial adalah terapi medikamentosa yang adekuat dan tindakan operasi timpanomastoidektomi dinding runtuh untuk menghilangkan sumber infeksi di telinga tengah.

\section{DAFTAR PUSTAKA}

1. Tyagi S, Srivastava M, Singh V, Kumar L. Chronic suppurative otitis media: clinical presentation of intracranial complications in rural area. $J$ of Evidence Based Med \& Hithcare. 2015;2(40):663944. DOI:10.18410/jebmh/2015/906.

2. Baig MM, Ajmal M, Saeed I, Fatima S. Prevalence of cholesteatoma and its complications in patients of chronic suppurative otitis media. Journal of Rawalpindi Med College. 2011;15(1):16-7.

3. Chole AR. Middle ear, mastoid, and temporal bone. Chronic otitis media, mastoiditis, and petrositis. In: Flint PW, Haughey $\mathrm{BH}$, Lund VJ, Niparko JK, Richardson MA, Robbins KT, editors. Cummings Otolaryngology Head \& Neck Surgery. Sixth edition. Philadelphia: Elsevier; 2015. p. 2139-55

4. Mustafa A, Kuci S, Behramaj A. Management of cholesteatoma complications: our experience in 145 cases. Indian Journal of Otology. 2014;20(4):45-7. DOI:10.4103/0971-7749.131862

5. Mansour S, Magnan J, Nicolas K, Haidar H. Middle ear disease: advances in diagnosis and management. First edition. Cham: Springer; 2018.

6. Dubey SP, Larawin V, Molumi CP. Intracranial spread of chronic middle ear suppuration. Am J Otolaryngol Neck Med Surg. 2010;31(2):73-7. DOI: 10.1016/j.amjoto.2008.10.001.

7. Mostafa BE, El Fiky LM, El Sharnouby MM. Complications of suppurative otitis media: still a problem in the 21st century. ORL. 2009;71:87-92.
DOI: $10.1159 / 000191472$.

8. Jain A, Arora N, Meher R, Passey JC, Bansal R. Intracranial complications of CSOM in pediatric patients: a persisting problem in developing countries. Int J Pediatr Otorhinolaryngol. 2017;100:128-31 DOI:10.1016/j.ijporl.2017.06.038

9. Dunbar $M$, Shah $H$, Shinde S, Vayalumkal J, Vanderkooi OG, Wei XC, et al. Stroke in pediatric bacterial meningitis: Population-based epidemiology. Pediatr Neurol. 2018;89:11-8. DOI: 10.1016/j.pediatrneurol.2018.09.005.

10. Tsze DS. Valente JH. Pediatric stroke: a review. Emergency Medicine International. 2011:1-10. DOI:10.1155/2011/734506.

11. Barath K, Huber AM, Stampfli $P$, Varga Z, Kollias S. Neuroradiology of cholesteatome. Am J Neuradiol. 2011;32:221-9. DOl:https://doi.org/ 10.3174/ajnr.A2052

12. Zarandy MM, Rutka J. Disease of the inner ear: a clinical, radiologic, and pathologic atlas. First edition. Berlin: Springer; 2010.

13. Arts HA, Adams ME. Intratemporal and intracranial complications of otitis media. In: Johnson JT, Rosen CA, Newlands, Amin M, Branstetters B, Casselbrant $\mathrm{M}$, et al, editor. Baileys head and neck surgery otolaryngology. Fifth edition. Philadelphia: Lippincot William \& Wilkin; 2014. p. 2398-409.

14. Hongisto AL. Acute severe complication of otitis media in children and adults [dissertation]. Helsinki. Medical Faculty of Helsinki; 2016.

15. Aquila I, Gratteri S, Sacco MA, Ricci P. A rare case of fatal meningoencephalitis with septic thromboembolism due to otitis media: a forensic case and review of literature. BMJ Case Rep. 2017:1-2. DOI:10.1136/bcr-2017-220594.

16. Rasul CH, Muhammad F, Hossain MH, Ahmed KU, Rahman M. Acute meningoencephalitis in hospitalised children in Southern Bangladesh. Malays J Med Sci. 2012;19(2):67-73.

17. Halperin JJ. Strokes in patients with bacterial meningitis with a focus on pneumococcus and lyme disease. In: Caplan L, Biller J, editors. Uncommon causes of stroke. Cambridge: Cambridge university press; 2018. p. 26-37.

18. Pasha HM, Mirsky DM, Streubel SO. Massive ischemic stroke as a complication of otitis media. 
Int J Pediatr Otorhinolaryngol. 2015;79(10): 1771 -

3. DOI:10.1016/j.ijporl.2015.07.025

19. Viswanatha B, Naseeruddin K. Lateral sinus thrombosis in otology: a review. Medit $\mathrm{J}$ Hemat Infect Dis. 2010;2(3):1-6. DOI:10.4084/MJHID. 2010.027.

20. Khajeh A, Mood BS, Soleimani GR. Pediatric meningo-encephalitis: A research on patients hospitalized in Zahedan, Southeatern Iran. Int $\mathrm{J}$ Infect. 2015;2(2):1-3. DOI: 10.17795/iji-23835

21. Del Brutto $\mathrm{OH}$. The neglected strokescerebrovascular. World Stroke Organization. 2015;10:14-5.

22. Brady MC, Kelly H, Godwin J, Enderby P, Campbell P. Speech and language therapy for aphasia following stroke (review). Cochrane Database of Systematic Review. 2016;6:1-68.

23. Yorgancilar E, Yildirim M, Gun R, Bakir S, Tekin R, Gocmez C, et al. Complications of chronic suppurative otitis media: a retrospective review.
Eur Arch Otorhinolaryngol. 2013;270:69-76. DOI: 10.1007/s00405-012-1924-8.

24. Kolegium IImu Kesehatan THT-KL. Buku acuan otologi. Jakarta: Kolegium IImu Kesehatan THT$\mathrm{KL} ; 2015$.

25. Ryu JH, Sohn IS, Do SH. Controlled hypotension for middle ear surgery: a comparison between remifentanil and magnesium sulphate. BJA. 2009;103(4):490-5. DOI: 10.1093/bja/aep229.

26. Farzanegan B, Eraghi MG, Abdollahi S, Ghorbani $\mathrm{J}$, Khalili A, Moshari R, et al. Evaluation of cerebral oxygen saturation during hypotensive anesthesia in functional endoscopic sinus surgery. Journal of Anaesthesiology Clinical Pharmacology. 2018;34 (4):503-6. DOI: 10.4103/joacp.JOACP_248_17.

27. Shoukry RA, Mahmoud AE. Controlled hypotension for functional endoscopic sinus surgery: a comparative study between magnesium sulfate and nitroglycerin. Ain-Shams Journal of Anaesthesiology. 2017;10(1):91-6. DOI: 10.4103/ asja.asja_46_16. 